\title{
On the leaves of Lathraea Squamaria and of some allied Scrophulariaceae.
}

\author{
BY \\ PERCY GROOM, M.A., F.L.S. \\ With Woodcut 7 .
}

T $\mathrm{N}$ a former paper (8) I have attempted to show that certain 1 saprophytes possess structures which enable them to get rid of any excess of water absorbed during their subterranean period of existence. In particular, I drew attention to the fact that saprophytes may possess stomata or peculiar epidermal patches on their underground shoots, which would facilitate the excretion of water either as liquid or vapour. It seemed probable that if my suggested explanation of these histological details were correct, some corresponding mechanisms might be discovered in other geophilous plants, and even in parasites accustomed to a partially subterranean mode of life.

Lathraea Squamaria suggested itself as a favourable subject for study, particularly as this plant can go through its whole cycle of life completely embedded in the soil; even forming cleistogamic subterranean flowers, and being capable of regenerating itself, when broken, by means of fragments of its

[Annals of Botany, Vol. XI. No. XIIII. September, 1897.] 


\section{Groom.-On the leaves of Lathraea Squamaria}

shoots. Further, this plant is very frequently found in soil which is very moist, or thoroughly wet, during the active vegetative season. It consists of a branched rhizome bearing many lateral roots. The roots spring from the sides of the rhizome and bear many lateral haustoria. The scales on the rhizome are arranged in a decussate manner and closely packed together. Each scale is pocket-like in form, with the mouth of the branched pocket-cavity opening on the lower face of the leaf. The epidermis lining the cavity represents the lower face of the leaf; it is devoid of stomata, but possesses hairs of two sorts:-(I) shortly-stalked capitate hairs; (2) peculiar dome-shaped hairs, often described as sessile glands. Both forms of hairs are glandular in appearance.

Proof of the excretion of water. A healthy flowering specimen of the plant was dug up from damp soil. Water was forced into the open ends of cut shoots by means of columns of mercury varying from I2-24 inches. Subsequent examination, after a lapse of some hours, showed that excretion had been so vigorous as to cause an outflow of water from the pockets of the younger leaves. I could not prove that there had been any excretion of water from the oldest leaves: there was not sufficient to cause an outflow from their pockets which contained both air and liquid. Larger parts of the plant kept, with rhizomes and roots dipping into water, and in a saturated atmosphere, did not excrete water sufficiently rapidly to cause any overflow from the pockets.

Owing to the peculiar form of these leaves, it is impossible to see directly which portions of the epidermis lining the pockets are responsible for the excretion of water: it was only possible to show that the water came from the cavities, and not from the epidermis of the upper face. Experiments of forcing coloured solutions into the leaves gave no satisfactory results. Fortunately a number of parasitic Scrophulariaceae (3) possess hairs like those of Lathraea ; I therefore examined several of these plants. 


\section{PEDICULARIS PALUSTRIS.}

Inasmuch as this plant lives in damp, even marshy, spots, it seemed probable that it would possess a water-excreting mechanism. Its much-lobed leaves have their margins recurved downwards. On the lower face of the leaf very numerous dome-shaped glands lie in furrows; over the fine nerves, especially near the margins, the glands are so numerous and large in some spots as to be in lateral contact to the exclusion of general epidermis. The vascular bundles of the leaf end in fine branches running close to the epidermis of the lower face, and therefore very near to dome-shaped glands. These fine nerves are separated from the upper epidermis by the well-developed palisade-parenchyma. The shortly-stalked capitate glands are exceedingly rare on the lower epidermis, but long-stalked hairs occur along the courses of the grosser nerves on that face. Numerous stomata are present on the lower face. Dome-shaped glands and stomata are absent from the upper face of the leaf; but a few capitate hairs occur above the courses of the nerves.

Excretion of water from the leaves. When water was forced up shoots under a pressure of I inch of mercury (in addition to the atmospheric pressure), it sufficed to cause an instantaneous excretion of water from the leaves. But when a pressure of several inches of mercury was applied, the water gushed out from the leaves with great rapidity. All the young leaves were dripping with moisture, and water was to be seen falling from the leaf-tips and running down the surface of the stem in swift little streams, also welling up, fountain-like, from the leaf-axils. The very violence of the outpour rendered it impossible to localize its exact source. Inverting an excreting branch served to demonstrate that the young leaves were mainly responsible for the excretion of water, and that in the first experiment the stem merely conducted the water down the hairy lines on its surface, and thus caused the overflow at the leaf-axils.

Histology of the dome-shaped glands. The excessive number 
of the dome-shaped glands, their close connexion with the tracheides terminating the vascular bundles, the separation of the latter from the upper face of the leaf, and finally the instantaneousness of the outflow, all pointed to the domeshaped glands as being responsible for the excretion of water. It seemed possible that a careful examination of these latter might reveal some permeable spot in their cuticularized walls. Each gland consists of four cells arranged to form a broad truncate cone with both base and apex convex. The single basal cell is the largest, and bulges into the tissue of a leaf.

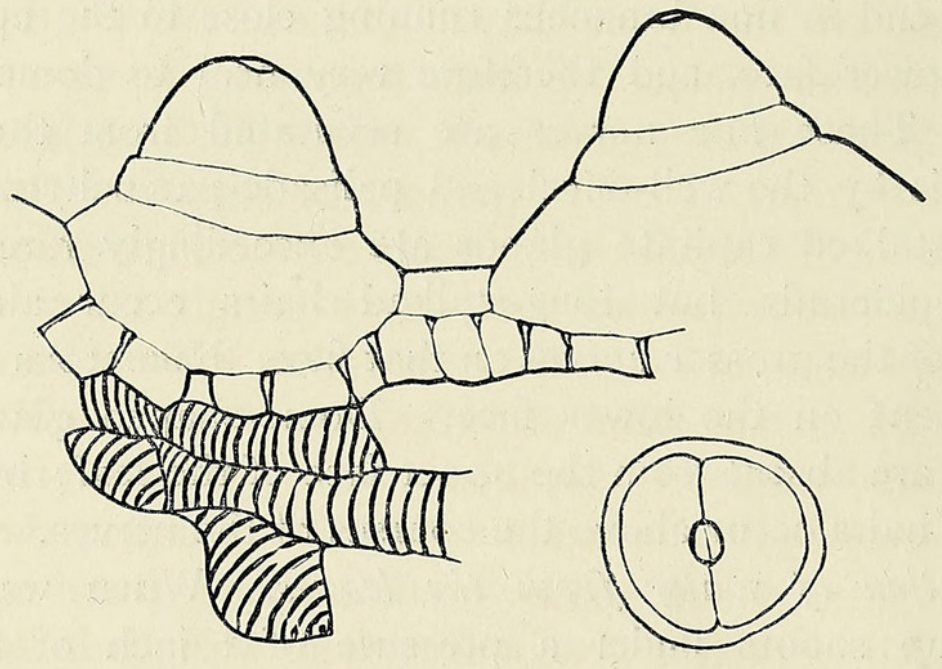

Fing 1.

Fig 2.

Woodcut 7 .

Above it succeeds a single discoid stalk-cell. The two remaining cells-the cap-cells-lie on the stalk-cell like two quadrants, roughly forming a hemisphere. The exposed walls of the gland are everywhere cuticularized, excepting at a circular spot in the centre of the apex at the junction of the two cap-cells. The cuticle is here interrupted by a large pore spanned by cellulose; but inasmuch as the cuticle is usually slightly raised round the margins of the pore, the latter in lateral optical section looks somewhat like a unilateral bordered pit. The pore is often blocked by a little plug of mucilage, which frequently protrudes outwardly in the form of a minute rounded knob. This mucilage in many of these 
glands contains solid calcium carbonate in small quantities. The external walls of the gland are marked with straight striations, which descend from the cap-cells to the basal cell as far as the general epidermis or to the point of contact of a contiguous gland. The cuticle is thickest on the wall of the stalk-cell. The transverse walls bounding the stalk-cell are thin, and consist of pure cellulose. The basal cell has conspicuous elongated pits on its lateral walls where they impinge on the basal cell of an adjoining gland. The fine vascular bundles have well-developed tracheides, and run close beneath the dome-shaped glands. When the bundle still possesses phloem (which therefore lies between the tracheides from the glands), a unique histological provision exists apparently for the purpose of directing the flow of water from the tracheides to the neighbouring glands. The cells of the nerve-parenchyma-sheath lying on the side away from the glands are closely set together without intercellular spaces ; but tracing them up to the sides of the bundle towards the glands, they are continuous with series of thin-walled parenchymatous cells which end finally under the glands. Distinct intercellular spaces occur amongst these connecting cells. Where their walls connect them with their fellow-cells they consist of pure cellulose, but where the walls bound the intercellular spaces they are cuticularized. The result is that the nerve-parenchyma-cells in contact with the tracheides communicate with the basal cells of the glands by thin-walled cells whose intercellular spaces form a network completely lined with cuticle. This arrangement, I suggest, enables water to flow, even under pressure, from the tracheides to the distant glands without being forced into the intercellular spaces. Where the intercellular spaces reach the lower wall of a basal cell, the cuticularization spreads over that region of the basal wall. Hence the lower wall of a basal cell is cuticularized in patches which correspond to the intercellular spaces; but consists of pure cellulose where it touches the subjacent parenchyma. Even when the vascular bundles have lost their phloem, the tracheides being still separated from the glands 


\section{Groom.- On the leaves of Lathraea Squamaria}

by several layers of cells, the same peculiar system of cuticularized canals is often visible. When, however, the bundles dwindle to a line of tracheides separated from the domeshaped glands by only one layer of parenchyma, I sometimes failed to detect cuticularization of the walls bounding the intercellular spaces. Near the margin of the leaf the tracheides are dilated and ampullate, and end against small parenchymatous cells which connect them with the basal gland-cells. These parenchyma-cells are always separated by considerable intercellular spaces: so that these marginal glands are built on precisely the same physiological plan as those in Lathraea, though not in the same histological manner.

\section{RHINANTHUS CRISTA-GALLI.}

As the excessively rapid discharge of water from the leaves of Pedicularis rendered it impossible to localize the exact source of the excretion of water, it seemed advisable to select a plant whose leaves possessed fewer dome-shaped glands. On this account I found Rhinanthus Crista-galli a suitable subject for investigation.

Each leaf is thick with indented margins which are slightly recurved towards the lower face. The nerves correspond with depressions on the upper face. The secondary nerves run from the midrib to the sinuses of the marginal indentations. The dome-shaped glands are very much less numerous than in the two preceding plants; they are limited to the lower face of the leaf, and only lie over the finest nerves, especially near the margin. The shortly-stalked capitate glands, distributed in the same manner, are very much more numerous, but they also occur in considerably smaller numbers in the furrows denoting the nerves, on the upper face of the leaf. Acuminate hairs are present on both faces of the leaf and on the margins. The stomata are numerous on the lower face, and a few occur on the upper face of the leaf.

Excretion of water by the Leaves. Plants rooted in grass- 
sods, and cut shoots into which water was forced under pressure, when kept in a saturated atmosphere, both gave the same results as regards the excretion of water. Water was slowly poured out by the young leaves. The observations on the source of the excreted water were at first quite unexpected. Rarely could any water be seen on the lower faces of the leaves (where the dome-shaped glands occur); whereas it was constantly visible in the sunken channels marking the upper faces of the secondary nerves, and extended as a thin film to the marginal sinuses. At first it appeared that this water could not have been excreted by the domeshaped glands: nor did it seem more likely that it could have been poured out by the capitate hairs or stomata, both of which are more numerous on the lower than on the upper face of the leaf. A few simple experiments cleared up the mystery. A shoot was held in an erect position with the leaves extended in the normal position, and a drop of water was placed on the lower face of an unmoistened leaf near the margin. The drop spread to the nearest marginal sinus, and extended itself in the form of a thin film along the sunken channel marking the upper face of the secondary nerve which supplied that sinus. A drop of water placed on the lower face of a leaf near the midrib (where no glands occur) did not move: it remained a drop. Finally, a drop of water placed on the upper face of a normally disposed leaf flowed along the sunken channels of the secondary nerves towards the channel of the midrib, but did not appreciably spread towards the margin. These experiments show, therefore, that in a normally excreting leaf, the water present in the peripheral portions of the nerve-channels in the upper face must have been excreted by the upper or lower face near the margin. Inasmuch as the histological details of the upper face of the leaf are essentially the same throughout, and there is no close connexion between the upper epidermis and the tracheides, nor any peculiarity in the epidermis near the margin, there is every reason to believe that the water is not excreted by the upper face. On the contrary, the portions of the lower 
face near the margins differ markedly from the parts near the midrib in their possession of dome-like glands, more numerous capitate hairs, and in the close histological connexion of these with the fine ends of the bundles.

Structure of the dome-shaped glands. These glands are built upon the same plan as those of Lathraea. Four cells with parallel lateral walls form a cap; a large biconvex cell lies below; and beneath it are four cells which, seen from above, look like the four quadrants of a disk, but have considerable round or elliptical intercellular space at the middle of each radius. The exposed walls of the gland are cuticularized everywhere save at the centre of the tip of the gland, where a pore like that of Lathraea occurs. The rim of the pore has a slightly thickened ring of cuticle, which often may be seen to project slightly outwards. A mucilaginous plug protrudes outwards in the form of a small hemisphere. In neither this plant nor in Pedicularis could I satisfy myself whether the plug is or is not perforated by an axial canal; but in Rhinanthus the plug, looked at from above, often seemed to have the appearance of being traversed by a vertical fine canaliculus. The tracheides and vessels underlying these glands are less developed and narrower than in Lathraea and Pedicularis, only near the leaf margin are the tracheides dilated. There is no cuticularization of the walls of the parenchymatous cells connecting the tracheides and the lowest series of gland-cells. The walls of the capitate hairs are externally cuticularized, there is no perforation of the cuticle.

\section{ODONTITES RUBRA.}

Rooted plants and cut shoots into which water was forced by mercury-pressure gave a very feeble excretion of water, even when kept in an atmosphere saturated with aqueous vapour. With the naked eye the drops could only be seen on the lower face of the leaf near the tip. My experiments with this plant were interrupted, consequently I can merely 
point out that the feeble excretion of water goes side by side with the numerical weakness in dome-shaped glands.

\section{CONCLUSIONS.}

So far I have shown that water is excreted in a liquid form by the leaves of Lathraea, Pedicularis, Rhinanthus, and Odontites, all of which possess dome-shaped glands on their lower faces. The following facts tend to prove that the water is poured out by the dome-shaped glands:-

I. The amount of water poured out is large when these glands are numerous (Lathraea, Pedicularis), and small when they are few in number (Rhinanthus, Odontites).

2. There are indications that only those portions of the leaf-surface which bear these glands excrete water (Lathraea, Rhinanthus).

3. The cuticle of these glands, in the three cases investigated, is perforated by a pore [Lathraea (1), Pedicularis, Rhinanthus] which renders that region of the wall permeable to water. I therefore regard this pore as a water-way, not as a channel through which mucilage may be excreted, as is generally supposed.

4. There is a close connexion between the tracheides in the fine bundles and these glands. I can confirm the accounts given by Scherffel (1), who alone of previous observers has correctly described the structure of these glands in Lathraea and their relations to the tracheides. As Scherffel points out, it is not true that a bundle of tracheides terminates under each gland. I find a network of tracheides very close beneath the epidermis lining the pocket. At certain points, especially at nodes of the network, certain broad ampullate tracheides bulge out towards the epidermis; but these lateral bulgings are less numerous than the dome-like glands, and, moreover, capitate hairs stand over them as well as dome-like glands. There is no trace of the cuticularization of the walls of subjacent parenchyma-cells where they bound intercellular spaces. In the plane scales on the floral axis of Lathraea, the dome- 


\section{Groom.-On the leaves of Lathraea Squamaria}

like glands are only found just outside the ends of the fine nerves.

The excretion of water does not take place through stomata, for they are absent from the subterranean scales in Lathraea: nor through special water-stomata, which are absent in all these plants (excepting that the teethstomata of the flat scales of Lathraea may be water-pores). There is every reason to believe that the capitate glands are not appreciably responsible for the excretion of water, for they are most numerous where excretion is very slow ( $R$ hinanthus), and show no intimate and necessary connexion with the ends of the vascular bundles. We are therefore entitled to-assume that the subterranean scale-leaves of Lathraea are the water-excreting organs of the subterranean plants, and that this excretion of water is vigorous, inasmuch as the domeshaped glands are numerous. This view is confirmed by a fact recorded by Mr. Gilburt (2) in his valuable little paper. Mr. Gilburt imagined that the dome-shaped glands excreted an acid sap which should serve to dissolve organic substances in the soil in order that the solution might be reabsorbed as food. This excretion of acid sap, he says, is abundant, for ' in the bank from which I have taken my material, and which is composed of a light, friable soil, the soil immediately surrounding the Lathrea (sic) was saturated with moisture, while all beside could be crumbled apart with the fingers.' A number of observers record that liquid as well as air is to be found in the pockets.

This view of the water-excreting function of the subterranean leaves of Lathraea is confirmed by reference to other allied types with subterranean scales. On these latter, as well as on the aerial leaves of the same plants, dome-shaped glands are found. I take the following anatomical facts mainly from Hovelacque's comprehensive work (3). Bartsia alpina is a root-parasite, usually living in humus-laden wet earth. Its aerial leaves have dome-shaped glands over the fine nerves near the margin of the lower face. The subterranean scales possess numerous dome-shaped glands and capitate 
hairs on the more peripheral portions of their lower faces. Pedicularis sylvatica grows in moist meadows. Its lowest, quite subterranean, leaves have backwardly recurved margins, and only under the reflected portions on the lower face are the numerous dome-shaped glands which are mingled with capitate hairs. Under these dome-shaped glands the fine nerves form an almost subepidermal network of tracheides. The foliage-leaves have recurved margins, and possess numerous dome-shaped glands on their lower faces, along the courses of the fine nerves: but the glands are not confined to the reflected portion. Tozzia alpina grows in wet alpine spots. The plane foliage-leaves possess on their lower faces, along the courses of the fine nerves, numerous dome-shaped glands and capitate hairs, which are especially abundant near the marginal sinuses. The wholly subterranean scales have their lateral margins very strongly reflected backwards, so that only small parts of their lower faces are visible. Numerous dome-shaped glands and capitate hairs clothe the inner (lower) surface of the reflected parts, and many dilated tracheides end directly under the epidermis of this region. The scales higher up have their lateral margins strongly reflected only on the more distal parts, and their basal portions are like the foliage-leaves as regards the disposition of the hairs. Thus these three Scrophulariaceous plants (the only ones on which I can find observations recorded with reference to subterranean scales and foliageleaves), growing in moist or wet soils, have a specially well-developed system of dome-shaped glands. So far as I can judge from Hovelacque's descriptions and figures, it scems that there is a relative increase in the development of these glands in the subterranean scales compared with the aerial leaves: this is very clearly marked in Tozzia and in Lathraea. This recalls the increased development of the physiologically equivalent water-excreting mechanism to which I called attention in the subterranean parts of saprophytes (8). It further leads us to anticipate that ordinary green geophilous plants will possess some similar mechanism. 


\section{Groom.-On the leaves of Lathraea Squamaria}

In all these cases, the considerable development of the waterexcreting apparatus in subterranean parts is to be correlated with the fact that the nature of the environment of these parts is such as to depress or entirely arrest transpiration underground.

It has been frequently suggested that both the domeshaped glands and the capitate hairs absorb nutrient liquids. Mr. Gilburt made a few experiments, and obtained evidence of the absorption of salts when supplied to these structures, and he therefore concluded that they naturally absorb solutions found in the soil. But a glance at Mr. Gilburt's statistics shows that the absorption of the salts was exceedingly slow, and in some instances could not be detected at all. I therefore regard his statistics as pointing out that the absorbent activity of the glands and hairs is so inconsiderable that we cannot suppose it to be of any fundamental importance to the plant. My own limited experiments confirm this view. By the use of very dilute solutions of gentian violet, by plasmolysis with common salt solution, or by staining with iodine (potassic-iodide solution) placed on an intact leaf of Lathraea, it was easy to show that the epidermis lining the pocket is more permeable to solutions than is the exposed epidermis. But only occasionally did I get any signs of a more rapid absorption of liquids by the dome-shaped glands than by the adjacent epidermal cells.

Object of the pocket-like form of the leaf. Cohn (4) suggested that these leaves might entrap and digest small organisms living in the soil, but he dismissed the view, as did Krause (5), Scherffel (1), and Heinricher (6): their evidence, together with the fact of the slow rate of absorption of liquids by the glands and hairs, is sufficient to show that the concavity of the leaves has nothing to do with the formation of a trap. I believe that the form of the leaf is adapted to protect the water-excreting glands (and possibly the capitate hairs), and is associated with the subterranean mode of life. The glands and hairs on the subterranean leaves have to contend, not only with climatic changes of 
one vegetative season, but have to endure the hardships of a winter, the dangers of saturation of the soil, and the percolative movements of the water in the soil. In confirmation of this view the following facts appear in reference to Lathraea and the parasitic Scrophulariaceae previously described in this paper:-(1) the dome-shaped glands are frequently confined to the recurved part of the leaf; (2) the glands are always very numerous in the strongly recurved types of leaves; (3) considering any particular plant, the relative number of glands on the leaf-surface is proportionate to the curvature of the leaf; (4) the curvature is strongest in the subterranean leaves. Even when the curvature is not more marked in the subterranean scales, chambers lined by glands are formed by the appropriate arrangement of the scales, at any rate in some plants (Bartsia).

Additional functions of the scale-leaves of Lathraea. I can add nothing to the information given by previous observers with reference to the capitate hairs. The leaves excrete a certain amount of chalk. Their fleshy mesophyll contains a great quantity of large grains of starch.

Conclusion. The pocket-like leaves of Lathraea are excretory organs and carbohydrate-reservoirs. Their concavity of form is assumed for the purpose of protecting the subterranean excretory mechanism; their succulence is associated with the necessity for providing house-room for the rich stores of reserve starch.

This research was conducted in the Botanical Laboratory of the University of Oxford. 
398 Groom.-On the leaves of Lathraea Squamaria.

\section{LITERATURE.}

1. Scherfffl: Die Driisen in den Höhlen der Rhizomschuppen von Lathraea Squamaria. (Mitth. a. d. Bot. Inst. z. Graz, 1888, Heft 2, pp. I87-2 I 2.)

2. Gilburt: On the Structure and Function of the Scale-leaves of Lathraea Squamaria. (Journ. Royal Microsc. Soc., Oct. I880, pp. 737-74I.)

3. Hovelacque: Recherches sur l'appareil végétatif des Bignoniacées, Rhinanthacées, Orobanchacées et Utriculariacées: Paris, I 888.

4. Cohn : (A paper not seen by me, in Jahresber. d. Schles. Ges.: Breslau, I877, pp. II 3 -II4.)

5. Krause: Beiträge zur Anatomie der Vegetationsorgane von Lathraea Squamaria. (Inaug. Diss. Breslau, 1879.)

6. Heinricher: Appendix to Scherffel's paper quoted above.

7. Bowman: On the parasitical connexion of Lathraea Squamaria and tie peculiar structure of its subterranean leaves. (Trans. Linn. Soc., Vol. xvi, I833, p. 399.)

8. Groom, P. : Contributions to the knowledge of Monocotyledonous Saprophytes. (Journ. Linn. Soc., XXXI, I895, pp. I49-21 5.)

\section{POSTSCRIPT.}

This investigation was concluded in June, 1896 , and the present paper was written, exactly as it now stands, in the autumn of the same year, but its publication has been unavoidably delayed. In the meanwhile, G. Haberlandt ${ }^{1}$ and Goebel $^{2}$ have almost simultaneously published papers on Lathraea. Both these investigators agree with me that the subterranean scales of Lathraea excrete water into their chambers, and that the specific function of some of the glands lining these cavities is to rid the plant of an excess of water. Haberlandt concludes that the capitate hairs alone are responsible for the excretion of water: whereas Goebel suggests that this function is performed especially by the dome-shaped glands (Schilddriisen). My paper, I think, contains sufficient proof that it is the dome-shaped glands which are the definite water-excreting organs-the hydathodes.

1 G. Haberlandt, Zur Kenntniss der Hydathoden: Jahrb. f. wissensch. Bot., xxx, Heft 4, I897.

${ }^{2}$ Goebel, Ueber die biologische Bedeutung der Blatthöhlen bei Tozzia und Lathraen: Flora, Bd. lxxxiii, Heft 3, 1897. 


\section{$2 \mathrm{BHL}$ Biodiversity Heritage Library}

Groom, Percy. 1897. "On the leaves of Lathraea squamaria and of some allied Scophulariaceae." Annals of botany 11, 385-398. https://doi.org/10.1093/oxfordjournals.aob.a088660.

View This Item Online: https://www.biodiversitylibrary.org/item/233542

DOI: https://doi.org/10.1093/oxfordjournals.aob.a088660

Permalink: https://www.biodiversitylibrary.org/partpdf/318472

\section{Holding Institution}

Smithsonian Libraries

\section{Sponsored by}

Biodiversity Heritage Library

\section{Copyright \& Reuse}

Copyright Status: Not in copyright. The BHL knows of no copyright restrictions on this item.

This document was created from content at the Biodiversity Heritage Library, the world's largest open access digital library for biodiversity literature and archives. Visit BHL at https://www.biodiversitylibrary.org. 